\title{
Prevalence of pediatric eye diseases in Assam, India — a hospital-based retrospective data
}

\author{
Pritam Dutta, Madhurjya Gogoi, Narayan Bordoloi \\ Chandraprabha Eye Hospital, Jorhat, Assam, India
}

\begin{abstract}
BACKGROUND: In a hospital setting, paediatric eye disease manifests itself in a complex network. It is essential to comprehend the scope of many common eye disorders in order to develop new evidence-based strategies for mitigating such disorders. The study aimed to investigate the hospital-based prevalence of pediatric ocular disorders of patients attending a tertiary eye care hospital.

MATERIAL AND METHODS: A three-year data from 2017-19 were extracted from the electronic medical records of Chandraprabha Eye Hospital, Assam, India. Refining the data was further carried out using the age criteria up to 18 years. The diagnosis for all the study subjects was taken into consideration and was further analyzed. The inclusion criteria included subjects within the range of 0-18 years reporting to the hospital during the study period. Subjects diagnosed with non-ocular problems, incomplete ophthalmological assessments, and those aged more than 18 years were excluded.

RESULTS: A total of 11807 relevant medical records were reviewed. Among the study subjects, 58.52\% ( $\mathrm{n}=6910$ ) were males. The mean $(\mathrm{SD})$ age was $11.9(4.8)$ years. Of the subjects $21.28 \%(\mathrm{n}=2513)$ were in age group $0-5$ years, $42.39 \%(\mathrm{n}=5006)$ - in $6-11$ years, and $36.31 \%(\mathrm{n}=4288)$ in $12-18$ years. A total number of 152 pediatric ocular abnormalities were identified from the reviewed files. Myopia alone accounted for $19 \%$ of all, followed by vernal keratoconjunctivitis with $14.7 \%$, followed by asthenopic presentation associated with non-strabismic binocular vision anomalies (7.4\%), congenital nasolacrimal duct obstruction (2.9\%), amblyopia (2.8\%), and ocular injuries (2.7\%). CONCLUSIONS: Refractive errors, allergic conjunctivitis, ocular injuries, amblyopia and squint, uveitis, congenital cataract, and non-strabismic binocular vision anomalies were identified as the most common pediatric ocular abnormalities seen in routine clinical practice, laying the groundwork for a standard protocol to evaluate and assess visual function in any case of pediatric anomaly.
\end{abstract}

KEY WORDS: pediatric eye disease; refractive errors; prevalence

Ophthalmol J 2021; Vol. 6, 215-222

\section{INTRODUCTION}

Vision is the primary component for an individual to perceive the world. The learning target begins in infancy, and the precision of a child's vision can significantly affect or change the learning ability. The more a problem with vision continues unaddressed, the more the child's brain learns to overcome the issue with vision. Several pediatric ocular abnormalities have been reported in the existing literature, which aims at portraying an epide- 
miological figure of anterior and posterior pediatric eye diseases in various parts of the world [1-4]. The World Health Organization (WHO) estimates that visual impairment affects 19 million children worldwide, often caused by uncorrected refractive errors, accompanied by untreated cataracts and glaucoma [5]. With proper medical consultation and effective treatment, $80 \%$ of visual impairments can be prevented [5].

Eye diseases and visual impairments in a child can develop several socio-economic problems. The pattern of childhood vision impairment has drastically changed in this present scenario compared to the 20th century. In a comparative data of trajectory change in childhood blindness between 1993 and 2006, the prevalence of disorders associated with visual impairment has increased [6]. Therefore, childhood eye diseases should be given priority, in particular in developing countries. Ironically, the hospital-based epidemiological studies of pediatric eye disease in Assam are confined. A cross-sectional study conducted at schools of Guwahati, Assam, showed a prevalence of myopia in about $81.92 \%$ [7]. Another study carried out at the Government schools of Dibrugarh, Assam, found approximately 39\% of the school-going children had a refractive error [8]. A prevalence of $1.75 \%$ amblyopic cases was re- ported in an observational study based on community outreach at Assam, which provides a rationale for school screening initiative need and appropriate referral and management. [9] Another community-based observational study found that refractive errors, allergic conjunctivitis, adnexal infections, and ocular trauma are common in rural areas of Assam. In contrast, uncorrected refractive errors along with cataracts and strabismus are more prevalent in urban areas [10]. Based on the above consideration, we aimed to present the hospital-based prevalence of pediatric ocular disorders of patients attending a tertiary eye care unit in Jorhat, Assam.

\section{MATERIAL AND METHODS}

This retrospective study was conducted at Chandraprabha Eye Hospital, Jorhat Assam. The study was approved by the institutional review board and adhered to the tenets of the Declaration of Helsinki. The inclusion criteria included subjects within the range of $0-18$ years reporting to the hospital during the study period. Subjects diagnosed with non-ocular problems, incomplete ophthalmological assessments, and those aged more than 18 years were excluded. The operational definitions of common eye disorders are tabulated in Table 1.

Table 1. Operational definitions of the common eye diseases

\begin{tabular}{|c|c|}
\hline Myopia & A condition in which the spherical equivalent objective refractive error is $\leq-0.50 \mathrm{D}$ in either eye [11] \\
\hline Emmetropia & $\begin{array}{l}\text { A state between myopia and hyperopia, in which "when parallel rays strike a physiologically normal eye, they are } \\
\text { refracted to converge upon the retina, where they focus, forming a circle of least confusion with the eye in a state } \\
\text { of rest [12] }\end{array}$ \\
\hline Amblyopia & $\begin{array}{l}\text { Unilateral or bilateral reduction in the visual acuity caused by pattern deprivation or abnormal binocular } \\
\text { interaction, for which no cause could be detected in the physical examination of the eye and which also could be } \\
\text { reversed by therapeutic measures in some cases [13] }\end{array}$ \\
\hline $\begin{array}{l}\text { Vernal keratoconjunctivitis } \\
\text { (VKC) }\end{array}$ & $\begin{array}{l}\text { Allergic inflammation of the ocular surface, involving the tarsal and/or bulbar conjunctiva that is persistent, } \\
\text { bilateral, at times asymmetrical, and seasonally aggravated [14] }\end{array}$ \\
\hline $\begin{array}{l}\text { Congenital nasolacrimal } \\
\text { duct obstruction (CNLDO) }\end{array}$ & Failure of the nasolacrimal duct drainage system, resulting in overflowing tears (also known as "epiphora") [15] \\
\hline Ocular injuries [16] & $\begin{array}{l}\text { Closed globe injury: No full-thickness wound of eye wall } \\
\text { Open globe injury: Full-thickness wound of the eye wall } \\
\text { Contusion: It is no (full-thickness) wound. This might be due to either direct energy delivery by the object or the } \\
\text { changes in the shape of the globe } \\
\text { Laceration: Full-thickness wound of the eyewall, caused by a sharp object } \\
\text { Penetrating injury: Entrance wound } \\
\text { Perforating injury: Entrance and exit wound }\end{array}$ \\
\hline Chemical burns & Injuries caused by either acid or alkali [17] \\
\hline Keratitis & Corneal inflammation characterized by corneal edema, inflammatory cell infiltration, and ciliary congestion [18] \\
\hline
\end{tabular}


Table 1. Operational definitions of the common eye diseases

\begin{tabular}{|c|c|}
\hline Keratoconus & $\begin{array}{l}\text { A condition that causes increasing corneal protrusion and thinning, resulting in irregular astigmatism and visual } \\
\text { impairment [19] }\end{array}$ \\
\hline Congenital corneal opacity & $\begin{array}{l}\text { group of diseases associated with loss of transparency in the corneal tissue at birth or during the first } 4 \text { weeks } \\
\text { of life [20] }\end{array}$ \\
\hline Corneal dystrophy & $\begin{array}{l}\text { a spectrum of inherited corneal abnormalities that are usually bilateral, symmetric, and slowly progressing, with } \\
\text { no link to environmental or systemic influences [21] }\end{array}$ \\
\hline Congenital cataract & opacification of the crystalline lens appearing at birth or shortly after [22] \\
\hline Dacryocystitis & $\begin{array}{l}\text { an inflammation in the nasolacrimal sac, typically caused by an obstruction within the nasolacrimal duct and } \\
\text { subsequent stagnation of tears in the lacrimal sac [23] }\end{array}$ \\
\hline Uveitis & $\begin{array}{l}\text { Inflammation of the uvea, which is comprised of the iris, ciliary body, and choroid. However, any part of the eye } \\
\text { can be inflamed. Based on the major anatomical site of the inflammation in the eye, uveitis is further categorized } \\
\text { into anterior, intermediate, posterior, and pan-uveitis [24] }\end{array}$ \\
\hline Coloboma & Absence of uveal (iris, ciliary body, choroid) tissue inside the eye [25] \\
\hline $\begin{array}{l}\text { Persistent hyperplastic } \\
\text { primary vitreous }\end{array}$ & $\begin{array}{l}\text { Developmental abnormality of the eye in which the embryonic vitreous and hyaloid vasculature do not fully form } \\
\text { [26] }\end{array}$ \\
\hline $\begin{array}{l}\text { Marcus Gunn Jaw-Winking } \\
\text { Syndrome }\end{array}$ & $\begin{array}{l}\text { Type of neurogenic congenital ptosis characterized by the movement of one upper eyelid in a rapid rising motion } \\
\text { each time the jaw moves [27] }\end{array}$ \\
\hline Down's syndrome & A genetic disorder resulting from dosage imbalance of genes located on human chromosome 21 (Hsa 21) [28] \\
\hline Goldenhar syndrome & $\begin{array}{l}\text { An unusual congenital disorder marked by severe craniofacial abnormalities as well as deformities of the spine, } \\
\text { heart, kidneys, central nervous system, and gastrointestinal tract [29] }\end{array}$ \\
\hline Marfan's syndrome & $\begin{array}{l}\text { A variable, autosomal-dominant disorder of connective tissue } \\
\text { usually linked with a mutation in fibrillin, and occasionally with a mutation in TGFBR1 or } 2 \text { [30] }\end{array}$ \\
\hline Congenital nystagmus & $\begin{array}{l}\text { Eye movement abnormality associated with involuntary oscillations } \\
\text { of one or both eyes [31] }\end{array}$ \\
\hline Cerebral palsy & $\begin{array}{l}\text { A group of persistent disorders affecting the development of movement and posture, causing activity limitation } \\
\text { that is linked to non progressive disturbances occurring in the developing fetal or infant brain [32] }\end{array}$ \\
\hline Congenital glaucoma & $\begin{array}{l}\text { A developmental condition occurring before the age of three years due to an obstruction preventing uniform } \\
\text { drainage of aqueous humor caused by abnormal development of the trabecular meshwork (TM) and anterior } \\
\text { chamber angle [33] }\end{array}$ \\
\hline Retinopathy of prematurity & Vaso-proliferative abnormality of the retina, commonly seen among preterm infants [34] \\
\hline Lattice degeneration & $\begin{array}{l}\text { A peripheral retinal degeneration associated with localized retinal thinning, overlying vitreous liquefaction, and } \\
\text { marginal vitreoretinal adhesion [35] }\end{array}$ \\
\hline Retinal detachment & Separation of the neurosensory retina from retinal pigment epithelium [36] \\
\hline Ocular albinism & $\begin{array}{l}\text { An autosomal recessive anomaly accompanied by complete absence or reduction of biosynthesis of melanin in } \\
\text { melanocytes [37] }\end{array}$ \\
\hline Chalazion & $\begin{array}{l}\text { Inflammatory, slow enlarging lesions of the eyelid occurring due to inflammation and obstruction of sebaceous } \\
\text { glands of the eyelids [38] }\end{array}$ \\
\hline Stye & Acute or chronic inflammation of the meibomian gland or gland of zeis in the eyelid [39] \\
\hline Astigmatism & $\begin{array}{l}\text { A refractive error where rays of light do not form a point focus; instead form two foci due to un uniformity in the } \\
\text { refractive media of the eye [40] }\end{array}$ \\
\hline
\end{tabular}

\section{Statistical analysis}

A three-year data from 2017-19 were extracted from the hospital's electronic medical records and were reviewed. Refining the data was further carried out using the age criteria up to 18 years. The diagnosis for all the study subjects was taken into consideration and was further analyzed. The outcome variable basically included the diagnosis made during the time of visit. Data were analyzed using Statistical Package for Social Sciences (SPSS). Para- metric method and univariate analysis were used to calculate the frequency and percentage.

\section{RESULTS Age and sex distribution}

A total of 11,807 subjects were recruited, of which $58.52 \%(\mathrm{n}=6910)$ were males. The mean (SD) age was 11.9 (4.8) years. Of the subjects $21.28 \%(\mathrm{n}=2513)$ were in age group $0-5$ years, 
Table 2. Frequency and percentage of anterior segment ocular disease

\begin{tabular}{|c|c|c|}
\hline Disease & Number & Percentage \\
\hline \multicolumn{3}{|l|}{ Corneal diseases } \\
\hline Defect epithelial cornea & 119 & 1.00 \\
\hline Disciform keratitis & 2 & 0 \\
\hline Keratoconjunctivitis & 101 & 0.9 \\
\hline Congenital cornea opacity & 48 & 0.4 \\
\hline Viral keratitis & 15 & 0.1 \\
\hline Keratoconus & 7 & 0.1 \\
\hline Corneal dystrophy & 1 & 0 \\
\hline Keratitis bacterial & 149 & 1.3 \\
\hline Keratomalacia & 2 & 0 \\
\hline Keratopathy band shaped & 2 & 0 \\
\hline Sclerocornea & 1 & 0 \\
\hline \multicolumn{3}{|l|}{ Ocular surface disorders } \\
\hline Stevens Johnson syndrome & 2 & 0 \\
\hline Xerophthalmia & 4 & 0 \\
\hline Dry eye syndrome & 3 & 0 \\
\hline \multicolumn{3}{|l|}{ Conjunctival disorders } \\
\hline Vernal keratoconjunctivitis & 1742 & 14.7 \\
\hline Blepharoconjunctivitis & 55 & 0.5 \\
\hline Sessile papilloma & 3 & 0 \\
\hline Neonatorum ophthalmia & 1 & 0 \\
\hline Subconjunctival hematoma & 21 & 0.2 \\
\hline Viral conjunctivitis & 19 & 0.2 \\
\hline Conjunctival cyst & 24 & 0.2 \\
\hline Giant papillary conjunctivits & 1 & 0 \\
\hline Pterygium & 2 & 0 \\
\hline
\end{tabular}

\begin{tabular}{|c|c|c|}
\hline Disease & Number & Percentage \\
\hline \multicolumn{3}{|l|}{ Eyelid disorders } \\
\hline Chalazion & 262 & 2.2 \\
\hline Telecanthus & 2 & 0 \\
\hline Molluscum contagiosum eyelid & 4 & 0 \\
\hline Stye & 191 & 1.6 \\
\hline Blepharitis & 103 & 0.9 \\
\hline Madarosis & 3 & 0 \\
\hline Euryblephron & 3 & 0 \\
\hline Ptosis congenital & 41 & 0.3 \\
\hline Entropion & 17 & 0.1 \\
\hline Blepharospasm & 8 & 0.1 \\
\hline Lid benign mass & 6 & 0.1 \\
\hline Trichiasis without entropion & 1 & 0 \\
\hline Eyelid cyst & 3 & 0 \\
\hline Meibomitis & 51 & 0.4 \\
\hline Blepharophimosis & 1 & 0 \\
\hline \multicolumn{3}{|l|}{ Lens disorders } \\
\hline Congenital cataract & 166 & 1.4 \\
\hline Traumatic cataract & 17 & 0.1 \\
\hline Aphakia & 16 & 0.1 \\
\hline Subluxation of lens & 7 & 0.1 \\
\hline Dislocation lens & 6 & 0.1 \\
\hline $\begin{array}{l}\text { Congenital cataract associated } \\
\text { with rubella syndrome }\end{array}$ & 3 & 0 \\
\hline Lenticonus congenital & 1 & 0 \\
\hline Spherophakia & 1 & 0 \\
\hline
\end{tabular}

$42.39 \%(\mathrm{n}=5006)-$ in $6-11$ years, and $36.31 \%$ $(\mathrm{n}=4288)$ in $12-18$ years. A total number of 152 pediatric ocular abnormalities were identified during the study period.

\section{Refractive error and associated anomalies}

Myopia was the most common refractive error being found (19.10\%), followed by astigmatism (15.50\%), hyperopia (1.80\%), and anisometropia $(0.20 \%)$. The prevalence of emmetropia was 10.90. However, the prevalence of amblyopia was $2.80 \%$, which comprised all its forms, including refractive, strabismic, anisometropic, and meridonial. The prevalence of non-strabismic binocular vision anomalies versus squint was $7.40 \%$ vs. $1.2 \%$.

\section{Anterior segment ocular abnormalities}

The most common anterior segment ocular abnormalities were: vernal keratoconjunctivitis
$(14.70 \%)$, congenital nasolacrimal duct obstruction $(2.90 \%)$, chalazion $(2.20 \%)$, stye $(1.60 \%)$, congenital cataract $(1.40 \%)$, bacterial keratitis $(1.30 \%)$, and corneal epithelial defect (1.00\%) (Tab. 2)

\section{Posterior segment ocular abnormalities}

The most common posterior segment ocular abnormalities found were: retinopathy of prematurity $(0.60 \%)$, lattice degeneration $(0.50 \%)$, retinal detachment $(0.30 \%)$, choroidal coloboma $(0.30 \%)$ and vitreous hemorrhage (0.20\%) (Tab. 3).

\section{Other ocular anomalies}

The less common ocular abnormalities noted were: microphthalmos, limbitis, preseptal cellulitis, episcleritis, proptosis, attention deficit hyperactivity syndrome (ADHD), anterior staphyloma, sebaceous cyst, endophthalmitis, phthisis bulbi, cortical blindness, enophthalmos, furunculosis, hydroceph- 
Table 3. Frequency and percentage of posterior segment ocular disease

\begin{tabular}{|c|c|c|}
\hline Disease & Number & Percentage \\
\hline \multicolumn{3}{|l|}{ Optic nerve disorders } \\
\hline Congenital glaucoma & 12 & 0.1 \\
\hline Pseudopapilledema & 1 & 0 \\
\hline Angle closure glaucoma & 3 & 0 \\
\hline Atrophy optic & 7 & 0.1 \\
\hline Neuritis optic & 5 & 0 \\
\hline Optic nerve head coloboma & 2 & 0 \\
\hline Neurofibromatosis & 2 & 0 \\
\hline Papilledema & 2 & 0 \\
\hline \multicolumn{3}{|l|}{ Retinal disorders } \\
\hline Leucocoria & 12 & 0 \\
\hline Retinopathy of prematurity & 1 & 0.6 \\
\hline Lattice degeneration & 3 & 0.5 \\
\hline Coloboma fundus & 7 & 0.1 \\
\hline Ocular albinism & 5 & 0.1 \\
\hline Macular cyst & 2 & 0 \\
\hline Retinal detachment & 2 & 0.3 \\
\hline Retinal vasculitis & 2 & 0 \\
\hline Toxoplasmo retinal scar & 2 & 0 \\
\hline Chorioretinitis toxoplasmic & 2 & 0 \\
\hline Coats disease & 68 & 0 \\
\hline Night blindness & 64 & 0 \\
\hline Coloboma retina & 9 & 0 \\
\hline Cysticercosis retina & 8 & 0 \\
\hline Stargardt's disease & 1 & 0 \\
\hline Retinitis pigmentosa & 39 & 0 \\
\hline Retinoschisis flat & 3 & 0 \\
\hline Scar chorioretinal & 3 & 0 \\
\hline Scar macula & 2 & 0 \\
\hline \multicolumn{3}{|l|}{ Vitreous disorders } \\
\hline Haemorrhage vitreous & 20 & 0.2 \\
\hline $\begin{array}{l}\text { Persistent hyperplastic primary } \\
\text { vitreous (PHPV) }\end{array}$ & 2 & 0 \\
\hline Vitritis & 3 & 0 \\
\hline
\end{tabular}

alus, a child with low vision, nanophthalmos and panophthalmitis. However, there were diseases with miscellaneous ocular involvement (Fig. 1).

\section{DISCUSSION}

This study illustrates the clinical pattern of common pediatric eye diseases, reporting a tertiary eye care center. Refractive error was one of the most common conditions noted, in which myopia alone accounts for $19.1 \%$. A meta-analysis carried out by Holden et al. (2016), estimated a global prevalence of 1406 million individuals with myopia and about 163 million with high myopia. As per the increasing trend of myopia, a prediction of $50 \%$ of the world's population developing myopia by 2050 was made too [41]. Prolonged near work and lesser outdoor activity are well-established risk factors for myopia progression. [42] Our study results showed that $50 \%$ of the cases among the myopic individuals are associated with near work, which is consistent with the review proposed by Grzybowski et al. (2020) [42]. This portrays the need for adapting necessary strategies to control myopia prevalence in hospital-based scenarios and a community setting.

Another noticeable result in this study was vernal keratoconjunctivitis (VKC), with a prevalence rate of $14.7 \%(\mathrm{n}=1742)$. The Allergies in Asia Pacific Study (AIAP) [43, 44] indicated that VKC is common among adults and school-going ages and affects their quality of life, school performance, and productivity. In their study, Duke et al. (2016) [45] found that $18.1 \%$ of the school-going children presented various grades of VKC. A similar result was found in our study. The subjects presented a gelatinous infraction with Trantas dots and a few with papillae, suggesting the association of the typical three clinical types of VKC.

Non-strabismic binocular vision anomalies (NSBVA) associated with asthenopic symptoms have been well documented in the existing literature [46-49]. Hussaindeen et al. (2017), in a population-based study, found that $31.5 \%$ in urban and $29.6 \%$ rural school-going children had NSBVA with a fact of the increase in the near visual demands thus, hampering their academic performance [49]. Convergence insufficiency was the most common NSBVA reported in both urban $(93 \%)$ and rural $(63 \%)$ children. Similar findings were portrayed in a cross-sectional study at Guwahati, Assam, by Magdalene et al. (2017). Authors found that approximately $70 \%$ of subjects between 10 and 20 years had NSBVA, with the most common convergence insufficiency [48]. This study result was in accordance with the previously reported studies, where $7.4 \%(\mathrm{n}=887)$ subjects had NSBVAs. However, the prevalence rate was not limited to either rural or urban populations due to the lack of specific information in patients' medical records. Moreover, the higher frequency reflects an upward tendency in convergence and accommodative abnormalities, 
which may be impacted by variables such as decreased outdoor activity, increased gadget usage, and uncorrected refractive errors. On the other hand, the prevalence rate would assist clinicians in creating a plan for various screening and clinical approaches to help diagnose and manage such instances earlier.

Amblyopia and its associated risk factors have always played a major concern as it is associated with a $1.2 \%$ lifetime risk of visual loss [50]. The prevalence of amblyopia rates varies due to the considered population and the conflicting definitions used in various studies. A population-based study carried out by Faghihi et al. found a prevalence rate of $4.6 \%$ amblyopia [51]. In contrast to the previous findings, another population-based study in southern India, conducted by Ganekal et al. (2013) found an amblyopia prevalence of $1.1 \%$ [52]. However, our study results were not consistent with any of them. The possible explanation could be the variation and the primary outcome measures difference in various studies. Another reason explaining the same would be the age group and the definition considered for amblyopia.

Cakmak et al. (2004) investigated the ocular injury profile in an eye care clinic and found that approximately $70 \%$ of the cases account in the age group of $0-15$ years, of which $95 \%$ of the cases were reported while playing [53]. These injuries further led to secondary complications such a retinal detachment, traumatic cataract, phthisis bulbi, and endophthalmitis. A similar pattern of ocular injuries of $2.7 \%(\mathrm{n}=325)$ was found in this study, along with $0.3 \%(n=33)$ of cases with chemical injury. These results suggest a provision of emergency care in a tertiary eye care unit, along with proper tools available for assessment and management. However, the involvement of the ocular structures following the injury remains unclear due to variation in the documentation of the injury site, at the diagnosis pattern in the patients' medical records.

A congenital cataract is responsible for around a tenth of the world's childhood blindness $[5,55]$. Since the etiology includes intrauterine infections, ionizing radiations, pre- and perinatal metabolic disorder, and hereditary means with and without associated syndromes [54], it becomes challenging for an eye care professional to rule out the exact cause and step with the intervention. Sheeladevi et al. (2016) in a systematic review, highlighted an overall global prevalence of 0.63 to 9.74/10000 children, respectively, with an incidence ranging from 1.8-3.6/10000 in high-income economies [55]. In contrast, the prevalence rate of childhood blindness owing to cataracts is about ten times higher in low-income nations than the higher-income ones [56]. However, in this study, a prevalence rate of $1.4 \%(n=166)$ congenital cataracts were found, and $(\mathrm{n}=3)$ were associated with syndromes. The results of this study are consistent with the study carried out by Mohan and Kaur (2017), where a total of patients $(n=165)$ were diagnosed with congenital cataracts, of which $72 \%$ were non-traumatic. Among them, a total of 5\% $(\mathrm{n}=6)$ had an association with rubella [57]. This implies a need for precautionary awareness during pregnancy and rubella vaccination to prevent further complications.

Retinopathy of prematurity is another increasing global trend for blindness. Limited health services in middle and low-income countries with geographic technical and capability differences may restrict the treatment of premature newborns, thus increasing the prevalence rate of ROP [58]. A retrospective 5 -year data by Le et al. (2016) in South India found an incidence rate of $2.3 \%(\mathrm{n}=66)$ ROP, among which $71 \%$ had a stage 1 ROP [59]. Our results are inconsistent with the results from the former study, where $0.6 \%(n=68)$ subjects had ROP. This suggests an effective screening protocol is vital to the timely detection and treatment of ROP.

On the other hand, neoplasms of the eye were found to be less common in this study. Olurin et al. (1971), described 191 histologically proven oculo-orbital tumors in the Nigerian population, of which two-thirds of the tumors were seen within the age of 20 years [60]. A study conducted by Modi et al. 2013 [61] in West India found retinoblastoma to be the common ocular tumor with a prevalence rate of $62 \%(n=46)$. However, these findings did not correlate well with our results, where the severity and prevalence of ocular tumors were less common. The reason could satisfy the fact that the difference in the climatic perspective and change in geographical status might contribute to our findings.

Moreover, uveitis in pediatric ages has also been reported in the literature. Narayana et al. (2002), in a study conducted in southern India, found 6.29\% of cases with pediatric uveitis involving all the types [62]. In 20 years of retrospective data from North India by Natasha et al. (2016) prevalence rate of pediatric uveitis was $3.8 \%$, with anterior uveitis being common of all [63]. Our study results also portrayed a prevalence of $0.6 \%(n=67)$ cases of uveitis, satisfying the results of the former studies. 
Sarosh et al. 2018, in their 2-year study period, found $45.9 \%$ from $0-10$ years and $29 \%$ within the age ranged from 10-20 years with a squint, of which esotropia was highly prevalent in approximately 60\% [64]. In our study $1.2 \%$ of patients $(\mathrm{n}=143)$ were diagnosed with ocular deviations. These results are inconsistent with mentioned findings. This builds up a matter of concern in managing these cases to prevent further development of secondary conditions like amblyopia if untreated. Thus, pediatric vision screening is thus a vital part of the early assessment of ocular conditions. Detecting vision-threatening ocular disorders early in the infant's development offers a huge opportunity to prevent further damage. The essential elements of infant screening are appropriate visual function assessment and rule out refractive errors, diagnosis of ROP, congenital cataract, corneal injury, retinoblastoma, strabismus, and amblyopia.

However, the limitation of the study includes the retrospective nature of the study design, limiting the diagnosis made with standard and uniform protocols due to variation in the diagnosis pattern from different examiners. Secondly, the outcome measures following management were not included owing to the loss of follow-up of maximum patients after their initial visit. Thus, future recommendations from this study include understanding the prevalence pattern of pediatric diseases in a longitudinal mode using proper diagnostic protocol and documentation of respective variables along with follow-up visits to understand the outcome of the treatment provided.

\section{CONCLUSION}

The study results highlighted refractive errors, allergic conjunctivitis, ocular injuries, amblyopia and squint, uveitis, congenital cataract, and non-strabismic binocular vision anomalies as the commonest pediatric ocular abnormalities seen in routine clinical practice. Our results set a base to evaluate precisely and assess the visual function in a standard protocol to be followed in any case of pediatric anomaly.

\section{REFERENCES}

1. Sushma H, Warad Vijaykumar G. Clinical Profile of Anterior Segment Eye Diseases in Children, Attending a Tertiary Care Hospital. EC Ophthalmology 7. 2017; 4: 90-95.

2. Sethi S, Sethi M, Saeed N, et al. Pattern Of Common Eye Diseases In Children Attending Outpatient Department Khyber Teaching Hospital. Pak J Ophthalmol. 2007; 24(4): 166-171.
3. Olusanya BA, Ugalahi MO, Ogunleye OT, et al. Refractive Errors Among Children Attending A Tertiary Eye Facility In Ibadan, Nigeria: Highlighting The Need For School Eye Health Programs. Ann Ib Postgrad Med. 2019; 17(1): 49-59, indexed in Pubmed: 31768156.

4. Ghosh S, Mukhopadhyay U, Maji D, et al. Visual impairment in urban school children of low-income families in Kolkata, India. Indian J Public Health. 2012; 56(2): 163-167, doi: 10.4103/0019-557X.99919, indexed in Pubmed: 22910628.

5. World Health Organization (WHO). Fact sheet on visual impairment and blindness. http://www.who.int/mediacentre/factsheets/fs282/ en/ (20 February 2021).

6. Gogate P, Kishore H, Dole K, et al. The Pattern of Childhood Blindness in Karnataka, South India. Ophthalmic Epidemiol. 2009; 16(4): 212-217, doi: 10.1080/09286580902999405, indexed in Pubmed: 19874141.

7. Sarma KD, Krishnatreya M. A study on refractive errors among the school children of Guwahati city. Int J Contemporary Med Res. 2016; 3(8): 2258-2260.

8. Sarawade SS, Bansode P. A study on the refractive status of school going children between age group of 10 to 15 years. MedPulse - Int J Ophthalmol. 2019; 13(3): 81-86, doi: 10.26611/10091337.

9. Magdalene D, Bhattacharjee $H$, Choudhury $M$, et al. Community outreach: An indicator for assessment of prevalence of amblyopia. Indian J Ophthalmol. 2018; 66(7): 940-944, doi: 10.4103/ijo.IJO_1335_17, indexed in Pubmed: 29941736.

10. Singh H, Kumar D, Kalita I, et al. Common Ocular Pathology in Paediatric Age Group (8-15 Years) in Rural and Backward Community of Assam. Int J Contemporary Med Res. 2018; 5(10): J1-J3, doi: 10.21276/ ijcmr.2018.5.10.23.

11. World Health Organization — Brien Holden Vision Institute. The impact of myopia. The Impact of Myopia and High Myopia. Report of the Joint World Health Organization-Brien Holden Vision Institute Global Scientific Meeting on Myopia. https://www.visionuk.org.uk/download/ WHO_Report_Myopia_2016.pdf.

12. Abrams D. (ed). Duke-Ëlder's Practice of Refraction. 10th ed . Elsevier Health Sciences, London 1993.

13. Von Noorden GK, Campos EC. Binocular vision and ocular motility; theory and management of strabismus. Mosby, St. Luis 1996.

14. Kumar S. Vernal keratoconjunctivitis: a major review. Acta Ophthalmol. 2009; 87(2): 133-147, doi: 10.1111/j.1755-3768.2008.01347.x, indexed in Pubmed: 18786127.

15. Schnall BM. Pediatric nasolacrimal duct obstruction. Curr Opin Ophthalmol. 2013; 24(5): 421-424, doi: 10.1097/ICU.0b013e3283642e94, indexed in Pubmed: 23846190.

16. Pieramici DJ, Au Eong KG, Sternberg P, et al. A system for classifying mechanical injuries of the eye (globe). The Ocular Trauma Classification Group. Am J Ophthalmol. 1997; 123(6): 820-831, doi: 10.1016/ s0002-9394(14)71132-8, indexed in Pubmed: 9535627.

17. Wagoner MD. Chemical injuries of the eye: current concepts in pathophysiology and therapy. Surv Ophthalmol. 1997; 41(4): 275-313, doi: 10.1016/s0039-6257(96)00007-0, indexed in Pubmed: 9104767.

18. Singh P, Gupta A, Tripathy K. Keratitis. StatPearls, Treasure Island 2021.

19. Rabinowitz Y. Keratoconus. Survey of Ophthalmology. 1998; 42(4): 297-319, doi: 10.1016/s0039-6257(97)00119-7, indexed in Pubmed: 9493273.

20. Rezende RA, Uchoa UBC, Uchoa R, et al. Congenital corneal opacities in a cornea referral practice. Cornea. 2004; 23(6): 565-570, doi: 10.1097/01.ico.0000126317.90271.d8, indexed in Pubmed: 15256994.

21. External diseases and cornea. In: Sutphin JE. ed. Basic and Clinical Sciences Course 2007-2008. American Academy of Ophthalmology, San Francisco 2007: 305-329.

22. Khan L, Shaheen N, Hanif Q, et al. Genetics of congenital cataract, its diagnosis and therapeutics. Egyptian J Basic Applied Sci. 2019; 5(4): 252-257, doi: 10.1016/j.ejbas.2018.07.001.

23. Taylor RS. Dacryocystitis. StatPearls, Treasure Island 2021.

24. Duplechain A, Conrady CD, Patel BC. Uveitis. StatPearls, Treasure Island 2021.

25. Chang L, Blain D, Bertuzzi S, et al. Uveal coloboma: clinical and basic science update. Curr Opin Ophthalmol. 2006; 17(5): 447-470, doi: 10.1097/01.icu.0000243020.82380.f6, indexed in Pubmed: 16932062. 
26. Persistent hyperplastic primary vitreous. Clin Eye Vis Care. 2000; 12(3-4): 131-137, doi: 10.1016/s0953-4431(00)00054-0, indexed in Pubmed: 11137427.

27. Ziga N, Biscevic A, Pjano MA, et al. Marcus Gunn Jaw-Winking Syndrome: a Case Report. Med Arch. 2019; 73(4): 282-284, doi: 10.5455/ medarh.2019.73.282-284, indexed in Pubmed: 31762566.

28. Asim A, Kumar A, Muthuswamy S, et al. "Down syndrome: an insight of the disease". J Biomed Sci. 2015; 22: 41, doi: 10.1186/s12929015-0138-y, indexed in Pubmed: 26062604.

29. Costea CF. Goldenhar Syndrome. J Clin Res Ophthalmol. 2015: 041-044, doi: 10.17352/2455-1414.000019.

30. Dean JCS. Marfan syndrome: clinical diagnosis and management. Eur J Hum Genet. 2007; 15(7): 724-733, doi: 10.1038/sj.ejhg.5201851, indexed in Pubmed: 17487218.

31. Dell'Osso L. Hereditary Congenital Nystagmus. Arch Ophthalmol. 1974; 92(5): 366, doi: 10.1001/archopht.1974.01010010378002.

32. Graham HK, Rosenbaum P, Paneth N, et al. Cerebral palsy. Nat Rev Dis Primers. 2016; 2: 15082, doi: 10.1038/nrdp.2015.82, indexed in Pubmed: 27188686.

33. Badawi AH, Al-Muhaylib AA, Al Owaifeer AM, et al. Primary congenital glaucoma: An updated review. Saudi J Ophthalmol. 2019; 33(4): 382 388, doi: 10.1016/.sjopt.2019.10.002, indexed in Pubmed: 31920449.

34. Gopal L, Sharma T, Ramachandran S, et al. Retinopathy of prematurity: a study. Indian J Ophthalmol. 1995; 43(2): 59-61, indexed in Pubmed: 8818311.

35. Semes LP. Lattice degeneration of the retina and retinal detachment. Optom Clin. 1992; 2(3): 71-91, indexed in Pubmed: 1463916.

36. Jalali S. Retinal detachment. Comm Eye Health. 2003; 16(46): 25-26, indexed in Pubmed: 17491854.

37. Marçon CR, Maia M. Albinism: epidemiology, genetics, cutaneous characterization, psychosocial factors. An Bras Dermatol. 2019; 94(5): 503-520, doi: 10.1016/.jabd.2019.09.023, indexed in Pubmed: 31777350.

38. Gilchrist $H$, Lee G. Management of chalazia in general practice. Aust Fam Physician. 2009; 38(5): 311-314, indexed in Pubmed: 19458801.

39. Willmann D, Guier CP, Patel BC. Stye. StatPearls, Treasure Island 2021.

40. Read SA, Collins MJ, Carney LG. A review of astigmatism and its possible genesis. Clin Exp Optom. 2007; 90(1): 5-19, doi: 10.1111/j. 1444-0938.2007.00112.x, indexed in Pubmed: 17177660.

41. Holden BA, Fricke TR, Wilson DA, et al. Global Prevalence of Myopia and High Myopia and Temporal Trends from 2000 through 2050. Ophthalmology. 2016; 123(5): 1036-1042, doi: 10.1016/j. ophtha.2016.01.006, indexed in Pubmed: 26875007.

42. Grzybowski A, Kanclerz P, Tsubota K, et al. A review on the epidemiology of myopia in school children worldwide. BMC Ophthalmol. 2020; 20(1): 27, doi: 10.1186/s12886-019-1220-0, indexed in Pubmed: 31937276.

43. Alemayehu AM, Yibekal BT, Fekadu SA. Prevalence of vernal keratoconjunctivitis and its associated factors among children in Gambella town, southwest Ethiopia, June 2018. PLoS One. 2019; 14(4): e0215528, doi: 10.1371/journal.pone.0215528, indexed in Pubmed: 30998721.

44. Thong BYH. Allergic conjunctivitis in Asia. Asia Pac Allergy. 2017; 7(2): 57-64, doi: 10.5415/apallergy.2017.7.2.57, indexed in Pubmed: 28487836.

45. Duke R, Odey F, Smedt SDe. Vernal Keratoconjunctivitis in Public Primary School Children in Nigeria: Prevalence and Nomenclature. Epidemiol Res Int. 2016; 2016: 1-6, doi: 10.1155/2016/9854062.

46. Jang JUn, Park IJ. Prevalence of general binocular dysfunctions among rural schoolchildren in South Korea. Taiwan J Ophthalmol. 2015; 5(4): 177-181, doi: 10.1016/j.tjo.2015.07.005, indexed in Pubmed: 29018694

47. Abdi S, Rydberg A. Asthenopia in schoolchildren, orthoptic and ophthalmological findings and treatment. Doc Ophthalmol. 2005;
111(2): 65-72, doi: 10.1007/s10633-005-4722-4, indexed in Pubmed: 16514487.

48. Deshmukh S, Magdalene D, Dutta $P$, et al. Clinical profile of nonstrabismic binocular vision anomalies in patients with asthenopia in North-East India. TNOA J Ophthal Sci Res. 2017; 55(3): 182-186, doi: $10.4103 /$ tjosr.tjosr 36 17.

49. Hussaindeen JR, Rakshit $\bar{A}$, Singh NK, et al. Prevalence of nonstrabismic anomalies of binocular vision in Tamil Nadu: report 2 of BAND study. Clin Exp Optom. 2017; 100(6): 642-648, doi: 10.1111/ cxo.12496, indexed in Pubmed: 27859646.

50. Webber AL, Wood J. Amblyopia: prevalence, natural history, functional effects and treatment. Clin Exp Optom. 2005; 88(6): 365-375, doi: 10.1111/j.1444-0938.2005.tb05102.x, indexed in Pubmed: 16329744.

51. Faghihi M, Hashemi H, Nabovati P, et al. The Prevalence of Amblyopia and Its Determinants in a Population-based Study. Strabismus. 2017; 25(4): 176-183, doi: 10.1080/09273972.2017.1391849, indexed in Pubmed: 29144181.

52. Ganekal S, Jhanji V, Liang Y, et al. Prevalence and etiology of amblyopia in Southern India: results from screening of school children aged 5-15 years. Ophthalmic Epidemiol. 2013; 20(4): 228-231, doi: 10.3109/09 286586.2013.809772, indexed in Pubmed: 23865603.

53. Cakmak SS, Unlu MK, Olmez G, et al. Penetrating eye injuries from southeastern Anatolia region of Turkey. Public Health. 2004; 118(8): 570-575, doi: 10.1016/j.puhe.2003.12.018, indexed in Pubmed: 15530937.

54. Rahi JS, Dezateux C. Congenital and infantile cataract in the United Kingdom: underlying or associated factors. British Congenital Cataract Interest Group. Invest Ophthalmol Vis Sci. 2000; 41(48): 2108-2114, indexed in Pubmed: 10892851.

55. Sheeladevi S, Lawrenson JG, Fielder AR, et al. Global prevalence of childhood cataract: a systematic review. Eye (Lond). 2016; 30(9): 1160-1169, doi: 10.1038/eye.2016.156, indexed in Pubmed: 27518543.

56. Foster A, Gilbert C, Rahi J. Epidemiology of cataract in childhood: A global perspective. J Cataract Refract Surg. 1997; 23(Supplement 1): 601-604, doi: 10.1016/s0886-3350(97)80040-5.

57. Mohan A, Kaur N. Pattern of presentation of pediatric cataract in tribes of hills of Western India: A hospital-based retrospective study at Global Hospital Institute of Ophthalmology, Mount Abu. J Clin Sci. 2017; 14(4): 178, doi: 10.4103/jcls.jcls_59_17.

58. Quinn GE. Retinopathy of prematurity $\bar{b}$ lindness worldwide: phenotypes in the third epidemic. Eye Brain. 2016; 8: 31-36, doi: 10.2147/ EB.S94436, indexed in Pubmed: 28539799.

59. Le C, Basani L, Zurakowski D, et al. Retinopathy of prematurity: Incidence, prevalence, risk factors, and outcomes at a tertiary care center in Telangana. J Clin Ophthalmol Res. 2016; 4(3): 119-122, doi: $10.4103 / 2320-3897.190785$.

60. Olurin 0, Williams A. Orbito-ocular tumors in Nigeria. Cancer. 1972; 30(2): 580-587, doi: 10.1002/1097-0142(197208)30:2<580::aidcncr2820300239 > 3.0.c0;2-t, indexed in Pubmed: 5051681 .

61. Modi P, Shah NA, Bhalodia JN. Orbital Tumors in Children: A Descriptive Study at Tertiary Care Centre. Nat J Med Res. 2013; 3(4): 362-366.

62. Narayana KM, Bora A, Biswas J. Patterns of uveitis in children presenting at a tertiary eye care centre in south India. Ind $\mathrm{J}$ Ophthalmol. 2003; 51(2): 129-132, indexed in Pubmed: 12831142.

63. Gautam N, Singh R, Agarwal A, et al. Pattern of Pediatric Uveitis at a Tertiary Referral Institute in North India. Ocul Immunol Inflamm. 2018; 26(3): 379-385, doi: 10.1080/09273948.2016.1239745, indexed in Pubmed: 27767364.

64. Sarosh R, Khan A, Rashi 0, et al. Profile of Strabismus at a Tertiary Care Hospital in Kashmir. Int J Contemporary Med Res. 2018; 5(6), doi: 10.21276/ijcmr.2018.5.6.8. 